Article

\title{
The Tripartite Structure of General Halachic Principles in the Bavli
}

\section{Uri Zur}

Moreshet Israel Department, Ariel University, Ariel 40700, Israel; uriz@ariel.ac.il

Received: 24 August 2017; Accepted: 20 November 2017; Published: 30 November 2017

\begin{abstract}
The paper introduces the tripartite structure used to shape principles of halachah. The unique design is expressed in a formal style consisting of three statements made by different sages, where each statement contains three halachic principles that have been grouped together in one place in the passage. The design of the halachic principles using a tripartite structure also clarifies the absence of additional halachic rules and the lack of material discussion of the halachah principles brought in the passage. The aim and the importance of this article is in presenting the design of halachic principles in the form of a tripartite structure, as well as how this pattern emerged and the special style of its appearance in the passage.
\end{abstract}

Keywords: structure; tripartite; principles; halachah; Eruvin; Bavli

The tripartite structure of certain discussion segments in the text of the Babylonian Talmud (the Bavli) has been a topic of study in with the context of an entire chapter in tractate Yevamot (Friedman 1978) More tripartite structures are to be found in some of the sugyot in tractate Eruvin in the Bavli (Zur 1999, pp. 368-93; 2016; Valler 1999), as well as, naturally enough, in other tractates which have not yet been studied in depth with a view to this issue.

The present article addresses general principles of halachic arbitration appearing in a single section of the Bavli, tractate Eruvin (46b), and featuring a distinctive formalized-stylized tripartite design. The general halachic principles mentioned there ad loc are indicative of the power relationships among different sages when it comes to determining the halachah when a difference of opinion arises among various tannaim.

\section{The Talmudic Sugya Showcasing a Tripartite Structure in Principles of Halachic Arbitration}

A. R. Jacob (Abramson 1982) ${ }^{1}$ and R. Zerika said:

1. The halachah ${ }^{2}$ is always in agreement with R. Akiba when he differs from a colleague of his, ${ }^{3}$

2. With R. Jose even when he differs from several of his colleagues, ${ }^{4}$

3. And with Rabbi when he differs from a colleague of his. ${ }^{5}$

1 (Abramson 1982); MS Oxford 366 add a label “KI.S.R"; Halachot Gedolot, Hildesheimer ed., vol. III, p. 12; See below, n. 21 the meaning of the label.

2 MS Vatican 109, the word: "Halacha" is missing.

3 MS Munich 95, the additional words appear: "But not against his colleagues"; Cf. MS Vatican 109: "Against his colleague"; Dikdukei Sofrim, Eruvin, p. 174, n. 100: "and not against his colleagues"; Cf. Sheiltot De R. Achai Gaon, Exodus, S.K. Mirsky Ed., vol. III, p. 95: "As for that halachah is in agreement with R Akiba [this means R. Akiba's view prevails] even against his colleagues."

4 MS Munich 95: "Even against his colleagues"; Halachot Gedolot, Hildesheimer ed., vol. III, p. 12; Idem, ibid., Halachot Ketzuvot diBnei Ma'arva, p. 17, n. 5.

5 MS Municn reads: "with Rabbi when he differs from his colleagues"; Abramson, ibid., pp. 230-31. 
B. R. Jacob b. Idi rule[d] in the name of R. Johanan:

1. In a dispute between R. Meir and R. Judah the halachah is in agreement with R. Judah, ${ }^{6}$

2. In one between R. Judah and R. Jose the halachah is in agreement with R. Jose.7

3. And there is no need to state that in a dispute between R. Meir and R. Jose the halachah is in agreement with R. Jose. ${ }^{8}$

For, since [it has been laid down that the opinion of the former is] of no consequence where it is opposed by that of R. Judah, can there be any question [as to its inconsequence] where it is opposed by that of R. Jose?

C. R. Assi ${ }^{9}$ said: I also learn ${ }^{10}$ that:

1. In a dispute between R. Jose and R. Simeon the halachah is in agreement with R. Jose,

2. For R. Abba ${ }^{11}$ has laid down on the authority of R. Johanan ${ }^{12}$ that in a dispute between R. Judah and R. Simeon the halachah is in agreement with R. Judah. ${ }^{13}$

Now [since the latter's opinion is] of no consequence where it is opposed by R. Judah can there be any question ${ }^{14}$ [as to its inconsequence] where it is opposed by that of R. Jose?

3. The question was raised: What [is the law where a ruling is a matter of dispute between] R. Meir and R. Simeon?-This is undecided. [Epstein ed.].

\section{The Genesis of the First Statement in the Tripartite Structure}

It is possible that initially only the first statement cited in the name of R. Jacob and R Zerika was part of the sugya's text. The statement made in the name of R. Jacob and R. Zerika was cited here in the sugya not only because earlier in the Talmudic text, general principles of Halachic arbitration were cited in the name of R. Johanan and R. Jacob b. Idi, ${ }^{15}$ but also because R. Judah's approach was previously mentioned, distinguishing between eruvei chatzerot [ritualized integration of courtyards] and eruvei techumin [integration of bounded areas], as was the approach associated with R. Jose, who distinguishes between the beginnings and the last remnants of an eruv. ${ }^{16}$

The redactors of this textual segment in the Talmud ad loc thought, therefore, that having cited the approaches associated with R. Judah and R. Jose, ${ }^{17}$ this was the most appropriate spot in the sugya for them to bring up the first rule by R. Jacob and R. Zerika. This, since they were interesting in establishing the general principle of halachic arbitration to the effect that the halachah is "with R. Jose even when he differs from several of his colleagues" [more than one single other sage opposing him in

\footnotetext{
bEruv., 52a; Ketubot 60b; yTrumot 3:1, 42a.

yTerumot 11:7, 48b.

bSan. 27a; CF. yBerachot 6:1,10b, the Halachah is in agreement with R. Meir, a ruling which goes against the general principle stated here; Also, B. Ratner, Ahavat Zion veYerushalaim, Berachot 6:2, pp. 151-52, s.v. R. Jacob: "the Yerushalmi issued a halachah ruling in accordance with R. Meir"; bBerachot 40b; (Ginzberg 1929, vol. II, p. 518).

9 R. Hananel, ibid.,: "Said R. Ashi" only; Dikdukei Sofrim, ibid., p. 174: "Said [R. Ashi]"; Hidushei HaMeiri, Eruv., 46b p. 325; Yad Mala'achi, Kelalei HaHei, p. 40: "That he had switched from R. Ashi to R. Assi".

10 MS Munich 95: "Said R. Ashi we also it said"; Also MS Vatican 109; MS Oxford 366; Halachot Gedolot, p. 12; R. Y. Alfassi, Eruv., 46b; Sefer Ha'Itim, Eruv., p. 61; R. Asher, Eruv., 46b.

11 Halachot Gedolot, ibid., p. 12: "R. Hiyya b. Abba”; R. Y. Alfassi, ibid., 46b; Hidushei HaMeiri, Eruv., 46b p. 325; Cf. bBetzah, 27a: "R. Zeriḳa, and some say R. Yirmiyah" or "R. Yirmiyah, and some say R. Zeriḳa".

12 MS Munich 95: "Yehoshu'a".

13 yTerumot 3:1, 42a, by analogy; Halachot Gedolot. Ibid., p. 12; Cf. Halachot Gedolot, ibid., Halachot Ketzuvot diBnei Ma'arva, p. 18: "The halachah is in agreement with R. Simeon".

14 Dikdukei Sofrim, ibid., p. 174.

15 bEruv., 46b; (Halivni 1998, pp. 99-100; Brandes 2002; 2007, pp. 515-35; Heger 2003, p. 256, n. 89; Hidary 2010, p. 61); On the term Halakhah, see for instance, (Bacher 1914, pp. 21-22; Urbach 1988, pp. 67-94).

16 bEruv., $46 \mathrm{~b}, 80 \mathrm{~b}$.

17 Cf., for instance, bKetubot 84a-b, where, following the dispute between R. Akiba and R. Tarfon, the general halachic rule is stated, as well: "The halachah is in agreement with R. Akiba as against his colleague".
} 
the discussion]," or, as per other versions, "[the halachah] with R. Jose as against his colleague,"18 so as to reach halachic rulings based on this principle. Thus making it clear that the halachah follows $\mathrm{R}$. Jose and not R. Judah. ${ }^{19}$

It would seem that the redactors of the text could have indicated only the general halachic principle with regard to R. Jose, without specifying the two other halachic principles in the first statement: "the halachah is always in agreement with R. Akiba when he differs from a colleague of his" and "with Rabbi when he differs from a colleague of his," considering that these two principles of halachic arbitration have no connection to that said earlier in the sugya. Yet considering that this statement had originally been made as a single unit consisting of these three general halachic principles, with some of the versions ${ }^{20}$ even containing an abbreviated label ( $\left(7\right.$ " $ר$ = KI.S.R. ${ }^{21}$ ) as a designation for the three of them together, no division was introduced among them.

\section{The Genesis of the Second Statement in the Tripartite Structure}

Insofar as the first statement associated with R. Jacob and R. Zerika is stylistically in keeping with the most generalized and inclusive principles of halachic arbitration-those indicating the power relationships between different sages - here the redactors of the sugya thought it appropriate to add two other statements dealing with general rules of halachic arbitration and couched in the same style, but formulated to provide greater detail-explicitly in the name of the particular sage specifiedso as to provide for a tripartite structure in the sugya based on three statements, each containing three general principles of halachic arbitration, with the statements designed in the "three by three" format (Friedman 1978, pp. 42-43) (as will be shown below).

It is for this reason that the second statement was added: "R. Jacob b. Idi rule[d] in the name of R. Johanan." This statement also marks out three general principles of halachic arbitration: "In a dispute between R. Meir and R. Judah the halachah is in agreement with R. Judah, in one between R. Judah and $R$. Jose the halachah is in agreement with R. Jose; and there is no need to state that in a dispute between R. Meir and R. Jose the halachah is in agreement with R. Jose."

In fact, the very phrasing in which the second statement is couched, "in the same sense did R. Jacob b. Idi rule," may be testimony that the second statement was added to the first because the second is "in the same sense" i.e., in the same language or expression as the first statement or very similar to it. That is to say, the second statement was added to form a sequel to the first one insofar as the second statement incorporates within it three general principles of halachic arbitration, just as the first statement does.

But then again, Rashi explains "in the same sense" as meaning: with regard to the halachic aspect of the issue. That is, as per Rashi's explanation, the same meaning that was intended concerning the statement made by R. Jacob and R. Zerika, was intended with reference to the words of R. Jacob b. Idi:

According to one, this is the halachah [so that the court must base its decisions on the ruling uttered by the Sage in question]; according to another, it is the position to incline toward for the Halachic court [even though it is not the required halachah or universal rule for general practice, it is recommended that the court guide itself by the positions of the Sages mentioned in making individual decisions]; and according to the third, it is the view to be treated as apparently acceptable. ${ }^{22}$

18 See above n. 4 in Halachot Ketzuvot.

19 Sefer Teshuvot HaRashba HaMeyuchassot LeHaRamban, Eruv., pp. 186-87.

20 See above, n.1, MS Oxford 366 and Halachot Gedolot.

21 The abbreviation in Hebrew, is composed of signal letters taken from the name of each of the three sages whose Halachic arbitration principles went into the making of the rule statement as a single whole: the letters kuf and yud, together reading KI and signifying the name of R. Akiba; the letter samekh, or S, indicating R. Jose; and resh, or R, standing for "Rabbi".

22 Rashi, Eruv., 46b s.v. "KaLashon HaZeh". 
But not everyone interprets this in the same way, and there are those who are of the opinion that "concerning the latter one it is appropriate"; i.e., only concerning the second statement, viz. "R. Jacob b. Idi rule[d] in the name of R. Johanan." 23 Moreover, Rashi does not say anything or interpret in this way with regard to the wording in the third statement: "R. Assi said: I also learn ...," from which it follows that there is a connection both in terms of content and in terms of phrasing style between the third statement and the second one, where the second is concerned only with general principles of halachic rulings as such, rather than engaging in questions of halachic validity (whether the statement has the weight of "halachah," a view "to incline toward," or a position to be treated as "apparently acceptable"). This is precisely how Rashi interprets the words as referring exclusively to the second statement, not with regard to the third one.

But even if we espouse Rashi's approach, that is, that the connection between the second statement and the third one involves the halachic aspect of the issue: "to what [extent were these meant to influence] the law in practice?" (meaning, how are the words of R. Jacob and R. Zerika to be taken: whether their statement has the weight of "halachah," a view "to incline toward," or a position to be treated as "apparently acceptable"), it becomes possible to say that "To what [extent were these meant to influence] the law in practice?" is a phrase specifically used to provide an opportunity for reworking the wording of the second statement: "in the same sense" with a view to the halachic validity aspect of the question. It will then be requisite to say the same thing with regard to the third statement, even though Rashi did not explicitly write this in so many words about the third statement.

But then, to counter this, there are those who see the phrase "in the same sense," 24 as "words ... which have no meaning." As per this approach, "To what [extent were these meant to influence] the law in practice?"25 is read in the same way; this way of reading the two phrases explains why they are missing in some versions of the text. ${ }^{26}$ Even without these phrases, according to this approach, there is a connection based on a fit in terms of content matter between the second statement and the first. This is since the second statement, which begins with the words, "R. Jacob b. Idi rule[d] in the name of R. Johanan," appears ad loc as the second statement noting merely the general principles of halachah, after the first statement, which was cited in the name of R. Jacob and R. Zerika, two sages who also specified general principles of halachah. The two statements were linked, such as to make one follow the other within the text, for this very reason.

It should be noted that the two phrases, "To what [extent were these meant to influence] the law in practice?" and "in the same sense," which bind together the first statement and the second, are, in fact, not necessary in the text ad loc. The text is in fact more readable without them, considering that without them the first and second statements read as a single sequence of general halachic principles and nothing more, as the two principles would be introduced one following the other with no additional phrases to interrupt the natural flow of the sequence.

\section{The Genesis of the Third Statement in the Tripartite Structure}

The third statement became joined to the preceding ones in a similar way, in light of the second statement. This is implied by the wording of the third statement itself: "R. Assi said: I also learn." The connection between the third statement and the second one is clearly conveyed by R. Assi's words, when he says, "I also learn ... " The wording suggests that he made his statement as an addendum to something that was stated earlier-in the second statement. R. Assi learns a single general principle of halachic arbitration: "in a dispute between R. Jose and R. Simeon the halachah is in agreement with R. Jose," deriving this from a different principle of halachic arbitration: "in a dispute between R. Judah and R. Simeon the halachah is in agreement with R. Judah." But R. Assi cannot arrive at this without

\footnotetext{
Ge'on Ya'akov, Eruv., 46b s.v. "KeR. Jose".

Cf. Halachot Gedolot, ibid., p. 12; Yavin Shemu'a, 5:1 p. 99 (231)

(Diner 1896, p. 43) s.v. "Sham ... Nir'ein".

R. Hananel, ibid., 46b.
} 
resorting to the connecting link provided by the general halachic principle of: "in one [a dispute] between R. Judah and R. Jose the halachah is in agreement with R. Jose." Even so, R. Assi is a student of R. Johanan's, ${ }^{27}$ and relies on this general halachic principle, which is to be found in the second statement, the second statement being cited in the name of R. Johanan as well; hence, a further link between the third statement and the second is evident. This is the reason why the third statement was joined as a third part to the first and second, thus making up and completing the tripartite construction.

Another factor in the genesis of the third statement in the tripartite setup is an additional connection between the third and second statements. This comes to the fore in the expression "for [lit., now]," which is used in both these statements but does not appear in the first one. This is due to the fact that the phraseology and style of the general halachic principles enunciated in the first statement preclude the possibility of saying "for [now that]..." This connection, conveyed by the expression "for [now that] ..." ", common only to the second and third statements, reinforces the possibility that only the first statement was originally intended (as has been noted above, in the section on the Genesis of the First Statement).

Then, as pointed out above, at a certain stage, two more statements were joined to the first one so as to complete the tripartite structure, where both these statements-our second and thirdwere redacted stylistically to resemble general principles of halachic arbitration, by adding the expression "for [now that]," which is identical in both these statements.

\section{Setting up the Tripartite Structure in the "Three by Three" Format}

It should be noted at the outset that the redactors of the talmudic text ad loc raised no questions about the words cited in the name of "R. Jacob b. Idi rule[d] in the name of R. Johanan" on the basis of things said by R. Jacob and R. Zerika, or the opposite. "R. Jacob b. Idi rule[d] in the name of R. Johanan" indicates certain general principles of halachah with reference to R. Jose: "in one [a dispute] between R. Judah and R. Jose the halachah is in agreement with R. Jose; and there is no need to state that in a dispute between R. Meir and R. Jose the halachah is in agreement with R. Jose." In light of all this, the words of "R. Jacob b. Idi rule[d] in the name of R. Johanan," are superfluous, considering that previously it had already been pointed out, in an overall general manner in the name of R. Jacob and R. Zerika, ${ }^{28}$ that the halachah is "with R. Jose even when he differs from several of his colleagues." This general rule can be taken to include "as against any single one of his colleagues," that is, whether against R. Judah, or against R. Meir, or against R. Simeon. ${ }^{29}$ The redactors of the talmudic section ad loc could thus have ignored the words of " $R$. Jacob $b$. Idi rule[d] in the name of R. Johanan," or raised objections against these words based on what was said by R. Jacob and R. Zerika, specified earlier, just as they had queried concerning that the halachah is "with Rabbi when he differs from a colleague of his" in the Yerushalmi. ${ }^{30}$ They could have also deliberated whether a difference of opinion between "R. Jacob b. Idi rule[d] in the name of R. Johanan," and R. Jacob and R. Zerika. ${ }^{31}$ But they did none of these things.

Alternately, the redactors of the sugya ad loc could have included only the words, "R. Jacob b. Idi rule[d] in the name of R. Johanan," and passed over any general halachic rules in the words of R. Jacob and R. Zerika, considering that later the talmudic text ad loc reads, "Does this then imply [it was asked] that only an individual opinion is against him? [And the reply was] Yes" [47a]. In other words, the general principle that when a single individual argues against him [R. Jose], and the reply was yes. This makes it sound like the particular rules of halachic arbitration which were said by

\footnotetext{
27 bShabbat 45b; Cf. Tosafot, Shabbat 45b s.v. "Lav"; Bava Batra 13ob; Pachad Yitzchak, p. 90b s.v. "R. Assi"; (Hyman 1964, vol. I, pp. 234-35) s.v. "R. Assi"; (Albeck 1969, pp. 228-29) s.v. "R. Assi”. 
"R. Jacob b. Idi ${ }^{32}$ rule[d] in the name of R. Johanan" in the second statement-with reference to "in one [a dispute] between R. Judah and R. Jose the halachah is in agreement with R. Jose", and with reference to "in a dispute between R. Meir and R. Jose the halachah is in agreement with R. Jose". All this goes against what was said by R. Jacob and R. Zerika, viz. that the halachah is "with R. Jose even when he differs from several of his colleagues" as a sweeping generalization. It would thus seem that there is no need at all for the first statement, made in the name of R. Jacob and R. Zerika (even though they enunciate two additional general principles of halachic arbitration: "the halachah is always in agreement with R. Akiba when he differs from a colleague of his," and "with Rabbi when he differs from a colleague of his"). This is especially noteworthy considering that the halachah does not, in fact, follow the principles they state (with reference to the general principle of halachic arbitration which reads, "[the halachah is in agreement] with R. Jose even when he differs from several of his colleagues"-against his fellows), insofar as R. Johanan disputes their position, maintaining that the halachah does not favor R. Jose over his fellows participants in halachic debates. ${ }^{33}$

Yet the redactors of the sugya opted, nonetheless, to include both the words of R. Jacob and R. Zerika, and those of "R. Jacob b. Idi rule[d] in the name of R. Johanan" as two distinct parts of the sugya, so as to create a tripartite structure, with the element common to all of its components being: three distinct general halachic principles included in each of these statements. This is why they did not discuss each of these general principles in isolation, nor connect between them in any associative or logical manner so as to have them shed light upon each other hermeneutically. ${ }^{34}$

It should be noted that the third halachic principle included in the second statement in the Bavli-viz. "and there is no need to state that in a dispute between R. Meir and R. Jose the halachah is in agreement with R. Jose"- appears superfluous (as borne out in particular by the words, "and there is no need to state ..." "). This is as should the halachah be determined in accordance with the approach of R. Judah as against R. Meir, and in accordance with R. Jose as against R. Judah, then it would be clear that the halachah is in agreement with R. Jose as against R. Meir. ${ }^{35}$ Then "goes the a fortiori argument, viz. that R. Meir and R. Jose-all the more so that the halachah is as R. Jose," ${ }^{\prime 36}$ except that the same "a fortiori argument, viz. that R. Meir and R. Jose the halachah is in agreement with R. Jose" was still enunciated in the second statement, such that with it the third general halachic principle in the second statement is completed (similar to the three halachic principles in the first statement), all as part of the triple structure of the "three by three" type.

In actuality, the third statement taken alone may indeed appear superfluous; however it, too, appears in our segment of the text ad loc so as to provide the third element of the tripartite structure. The third statement is in fact composed of two general halachic principles, which have a decisive impact on halachic arbitration: "in a dispute between R. Jose and R. Simeon the halachah is in agreement with R. Jose," and "in a dispute between R. Judah and R. Simeon the halachah is in agreement with R. Judah." This is exactly the same situation as with the general halachic principles cited earlier, in the second statement: they contain principles of halachic arbitration resolved using phrases that follow the pattern of "the halachah is in agreement with so-and-so."

The superfluity of the third statement comes to the fore as early as the first general halachic principle encountered in it: "in a dispute between R. Jose and R. Simeon the halachah is in agreement with R. Jose," which is learned by R. Assi ${ }^{37}$ when analyzing details as based on the second general principle in this statement, viz. "for R. Abba has laid down on the authority of R. Johanan that in a dispute between R. Judah and R. Simeon the halachah is in agreement with R. Judah." But the first

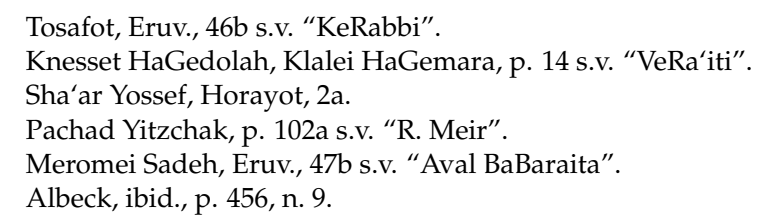


general principle learned by R. Assi is superfluous, since R. Jacob and R. Zeriḳa have already said that the halachah is with "R. Jose even when he differs from several of his colleagues." All the more so in the case "as against his colleague [a single individual, rather than a group opposing his view]." 38 This makes it clear that even without the derived conclusion reached by R. Assi, the halachic principle of "in a dispute between R. Jose and R. Simeon the halachah is in agreement with R. Jose" naturally follows from the halachic principle of "as R. Jose differs from his colleagues." Thus, just as the first statement is superfluous, there is no need for the second statement either; this is the statement which forms the basis for R. Assi who says that: "in a dispute between R. Judah and R. Simeon the halachah is in agreement with R. Judah" ${ }^{\prime 39}$ for the purpose of deriving the first general principle. It finds its justification only if we acknowledge that, as noted, these two general halachic principles were nonetheless made a part of his words-as a third statement-for purposes of compiling the general halachic principles in the third statement, as well, as following a certain order (just as the first two general halachic principles), thus comprising the tripartite structure.

\section{The Problem of the Absence or Non-Absence of a Third General Halachic Principle in the Third Statement}

As noted, in the third statement there is no third general halachic principle, in contrast to that found in the two preceding statements, which each have three general halachic principles. Indeed, it follows naturally in light of the associations implied in the second and third statements that the third halachic principle in the third statement must be in reference to the tannaim R. Meir and R. Simeon, dictating that the halachah should be arbitrated in accordance with one of their positions. Yet it appears that the redactors of the sugya had not reached a general resolution vis-à-vis R. Meir and R. Simeon. ${ }^{40}$ Even so, they still conveyed the problem of the power relationship between them, representing it as a problem with no solution ("The question was raised" and "This is undecided") as an alternative to a decisive general halachic rule. All this is brought so as to fill the empty space left by the missing third general halachic principle in the third statement.

Nonetheless, the possibility remains that, even so, a third halachic principle was resolved upon and specified in the third statement. This is the impression one has in light of the textual variants surfacing in R. Asher's version. According to R. Asher's version in tractate Avodah Zarah: "And another proof is in that according to R. Simeon it may be ... arguing against R. Meir, and the halachah is in agreement with him [R. Simeon], as it states in Eruvin [46b], the chapter beginning with the words, 'He whom gentiles, or evil spirit, have out .. . '[Eruv. 41b]." ${ }^{41}$ It follows from his comment that a decisive halachic principle is defined in Eruvin: "[In a dispute between] R. Meir and R. Simeon the halachah is in agreement with R. Simeon" [rather than in need of resolving or "undecided"]. But R. Asher's version of the text in Eruvin [46b] is: "The question was raised: What [is the law where a ruling is a matter of dispute between] R. Meir and R. Simeon?-This is undecided," identical to the text of the printed version (Vilna) of the sugya [Eruv. 46b], with no difference (as stated above in Avodah Zarah). Given the variant reading in these comments by R. Asher, it is unclear what the text of Eruvin that he was working with actually said. If the version of the text which reads: "The question was raised: What [is the law where a ruling is a matter of dispute between] R. Meir and R. Simeon?This is undecided," was in fact not part of his version of the text in Eruvin, as seems to follow from his words in tractate Avodah Zarah, then it may be that instead of the words "The question was

38 Abramson, ibid., p. 245, n. 69.

39 R. Hananel, Eruv., 46b. First, the general principle was cited in the words of R. Abba, "in a dispute between R. Judah and R. Simeon the halachah is in agreement with R. Judah," and then the general principle in the words of "Said R. Ashi, in a dispute between R. Jose and R. Simeon the halachah is in agreement with R. Jose." The opposite of the order of the general principles in the sugya and presented as general halachic principles standing each on its own, without any analogy links among them.

40 Birkei Yossef, Even HaEzer 17:12 s.v. “U’Var Min Den”; (Heger 2003, p. 267, n. 90).

41 R. Asher, Avodah Zarah 38b: 34. 
raised ..." " here in the sugya in the Bavli, there was a decisive third general halachic principle in the third statement, as found in (R. Asher's statement in Avodah Zarah and) the Yerushalmi: "[in a dispute between] R. Meir and R. Simeon-the halachah is in agreement with R. Simeon," ${ }^{42}$ and as seen in other places ${ }^{43}$ and in the words of various commentators and poskim [halachic authorities]. ${ }^{44}$ (There are also those who are of the opinion that the origin of this general principle is not necessarily from the Yerushalmi (Danzig 1999, p. 208).)

Accordingly if, according to R. Asher's version of the text, there was a third general halachic principle in the third statement here in Eruvin—as seems to follow based on R. Asher's words in tractate Avodah Zarah - then it follows that the phrasing of the third statement also consisted of three decisive general halachic principles, similar to the three decisive halachic principles in the two preceding statements-and not as a problem impossible to resolve and therefore left undecided. This seems the most likely in the sugya, that each of the three statements should contain three decisive general halachic principles, delivered by means of three statements and together forming a tripartite structure of the "three by three" type.

Similarly, a tripartite structure of this type makes it possible to explain the absence of any other general halachic principles in these statements. For instance, in the first statement, in connection with Rabbi ("IIn a dispute between] Rabbi and R. Simeon b. Gamliel the halachah is in agreement with R. Simeon b. Gamliel"45) or in the second statement in connection with R. Judah ("IIn a dispute between] R. Judah and R. Eliezer b. Jacob the halachah is in agreement with R. Eliezer b. Jacob" ${ }^{\prime 46}$ ), the intention is to avoid violating the tripartite structure of the "three by three" type, which the sugya conveys.

In light of everything that has been said, in this way the talmudic text ad loc becomes a showcase display of three statements, each containing three general halachic principles, forming a complete unit designed as a tripartite structure of the "three by three" format.

Conflicts of Interest: The author declares no conflict of interest.

\section{References}

Abramson, Shraga. 1982. LeToledot Nossach. Seder Tannaim VeAmoraim. In Studies in Rabbinic Literature Bible and Jewish History. Edited by Yitzhak Gilat, Chaim Levine and Zvi Meir Rabinowitz. Ramat-Gan: Bar-Ilan University.

Albeck, Chanoch. 1969. Mavo LaTalmudim. Tel Aviv: Dvir.

Bacher, Wilhelm. 1914. Tradition und Tradenten in den Schulen Palästinas und Babyloniens. Leipzig: Buchhandlung G. Fock.

Brandes, Yehuda. 2002. The Begining of the Rules of Halachic Adjudication. Ph.D. Dissertation, Hebrew University, Jerusalem, Israel.

Brandes, Yehuda. 2007. Mahpechat HaPessika shel R. Yochanan: Klalei HaPessika. In BeDarkhei Shalom Studies in Jewish Thought Presented to Shalom Rosenberg. Edited by Benjamin Ish-Shalom. Jerusalem: Beit Morasha of Jerusalem Press.

Danzig, Neil. 1999. Mavo LeSefer Halakhot Pesuqot im Tashalum Halakhot Pesuqot, 2nd ed. New York and Jerusalem: The Jewish Theological Seminary of America.

Diner, Yossef Zvi. 1896. Hagahot al Massechet Eruvin. Frankfurt am Main: Slobotzky.

Friedman, Shamma. 1978. A Critical Study of Yevamot X with a Methodological Introduction. Jerusalem and New York: The Jewish Theological Seminary of America.

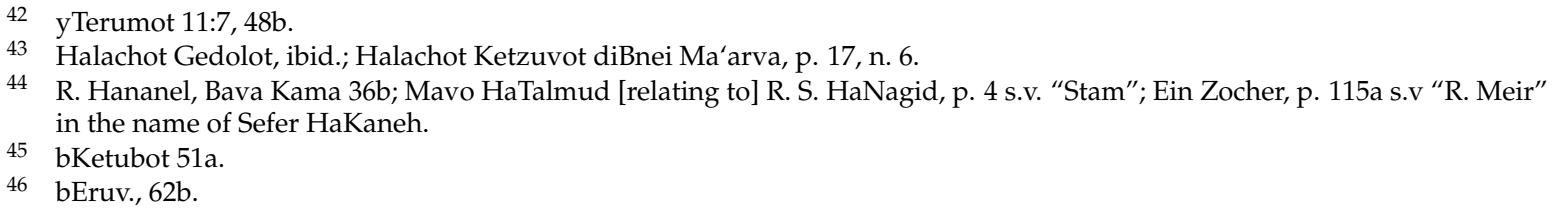


Ginzberg, Louis. 1929. Texts and Studies, Genizah Studies. New York: The Jewish Theological Seminary of America, vol. II.

Halivni, Ephraim Bezalel. 1998. The Rules for Deciding Halakha in the Talmud. Lod: The Habermann Institute for Literary Research.

Heger, Paul. 2003. The Pluralistic Halakhah. Berlin and New York: Walter de Gruyter.

Hidary, Richard. 2010. Dispute for the Sake of Heaven: Legal Pluralism in the Talmud. Providence: Brown University. Hyman, Aaron. 1964. Toldoth Tannaim Ve'Amoraim. Jerusalem: Kirya Ne'emanah.

Urbach, Ephraim Elimelech. 1988. Massoret VeHalakha. In Idem, the World of the Sages: Collected Studies. Jerusalem: Magnes.

Valler, Shulamit. 1999. Women and Womanhood in the Talmud. Atlanta: Scholars Press.

Zur, Uri. 1999. Orr Israel, Editorial Considerations in the Redaction of Sugyot in Tractate Eruvin of the Babylonian Talmud. Lod: The Habermann Institute for Literary Research.

Zur, Uri. 2016. The Tripartite Structure of the Sugyot: Studies in Tractate Eruvin of the Babylonian Talmud. Ariel and New York: Ariel University Press \& David Publishing Company.

(C) 2017 by the author. Licensee MDPI, Basel, Switzerland. This article is an open access article distributed under the terms and conditions of the Creative Commons Attribution (CC BY) license (http://creativecommons.org/licenses/by/4.0/). 